\title{
The EfFect of Crude Protein Halimeda SP. ON CYPRinus CARPIO INFECTED KOI HERPES VIRUS ON EXPRESSION OF MAJOR Histocompatibility COMPleX Class-1
}

\author{
Uun Yanuhar $^{1 *}$ Rika Wahyuningtyas ${ }^{2}$ \\ ${ }^{1)}$ Laboratory of Water Sciences, Faculty of Fisheries and Marine Science, University of Brawijaya, \\ Indonesia \\ Jl. Veteran Malang, East Java, 65144. \\ ${ }^{2)}$ Magister Program, Double Degree Program of Fisheries and Marine Science of Faculty, University \\ of Brawijaya, Indonesia \\ *Corresponding author: uunyanuhar@yahoo.com
}

\begin{abstract}
Halimeda sp. is a species of macroalgae that grow abundant in Indonesia. The utilization of Halimeda especially protein for disease prevention caused by the virus has not been done to the fish. The purpose of the study is to know the treatment of crude protein Halimeda sp on Cyprinus carpio infected by Koi Harvest Virus (KHV) on the expression of Major Histocompatibility Complex (MHC) class 1. MHC class-1 is one of the immune adaptive response on fish like in this C. carpio. The methods are isolation of crude protein Halimeda sp, purification of crude protein, Haemagglutination (HA) test and dot blot test. The result shows crude protein of Halimeda sp. can produce adaptive immune response like MHC class 1. MHC class-1 has the function of the immune system for maintenance of direct virus invasion. Responsible to treatment of crude protein Halimeda sp. on C. carpio can be showed quantitatively using the dot blot test result. The conclusion is the crude protein of Halimeda sp. able to activate the MHC class I and to inhibit the proliferation of the KHV and maintenance of the fish cell of C. carpio..
\end{abstract}

Keywords: Cyprinus carpio, Halimeda, KHV, protein, MHC-I,

\section{INTRODUCTION}

Major histocompatibility complex (MHC) is a group of genes located on a single chromosome in vertebrates that encode proteins with highly polymorphic. The proteins were transferred to the surface of the cells carrying foreign antigens to be presented by the $\mathrm{T}$ cells to initiate an immune response [1]. MHC class I play a role in intracellular antigen present in the cytosol to the cytotoxic $\mathrm{T}$ cell (Tc cells), which is usually a nucleic acid of a virus or a bacterial infection that is intracellular. Tc cells will trigger the infected cells to hold apoptosis (programmed cell death) using granzyme and perforin. Granzyme creates pores in cell membranes and induces apoptosis [2]. The proteins expressed by MHC class I and antigen presenting cells (APC) were instrumental in presenting extracellular antigens to $\mathrm{T}$ helper cells. It will initiate a humoral immune responses.

\footnotetext{
* Corresponding Author.

E-mail: uunyanuhar@yahoo.com

(C) 2017 at http://jfmr.ub.ac.id
}

MHC genes have been reported to exist in all classes of vertebrates with the exception of a very primitive fish that had no jaws [3]. The recognition of viral peptides in the context of MHC class I molecules by cytotoxic $T$ lymphocytes is a key event in the elimination of virus-infected cells [4].

Koi herpes virus (KHV) is the causative agent of a lethal disease in koi and common carp [5]. The brood stocks showed poor appetite, lethargy, abnormal swimming behaviour with gasping movements in shallow water and increased mucus secretion. Histopathologically, the gill showed diffuse necrosis of the bronchial epithelial cells and diffuse lymphocyticmonocytic interstitial nephritis with necrosis of the tubular epithelial cells [6].

In the ocean, aquatic plants are scattered. The diversity of marine biota in Indonesia is very large and is a potential source of wealth. 
Macroalgae and microalgae are the potential Indonesian natural resources. Some types of macroalgae such as Halimeda, Gracilaria sp.,Sargassum sp., Chlorella sp., and Spirulina sp., were researched and were found to have a high economic value [7]. Seaweeds like Halimeda sp are considered as a source of bioactive compounds for antioxidant, antiviral, antifungal and antimicrobial activities. It has been detected in brown, red and green algae [8]. Halimeda sp ability to modulate the non -specific defense system in fish and shrimp among possible other than by their specific immunostimulatory compound, also by polyphenol compounds which have high antioxidant activity. Halimeda is true role as a very significant organism is becoming more evident from a wide variety of investigations. This research was conducted by inducing the cyprinus carpio infected by KHV with crude protein isolated from macroalgae Halimeda sp on expression of MHC class I.

\section{MATERIAL AND METHOD}

\subsection{Collection of Halimeda sp.}

Macroalgae Halimeda sp. species Halimeda opuntia was collected from the waters of the Kupang Bay, Nusa Tenggara Timur, Indonesia. The collected macro alga taken as $\pm 2000 \mathrm{~g}$ wet, placed in a sterile box 4 each 500 gram stored at $80^{\circ} \mathrm{C}$ as a sample.

\subsection{Acclimatization Cyprinus carpio}

Acclimatization is intended to fish to make adjustments to some environmental factors. Stocking is done slowly out of the plastic bag up into the pond. Seed goldfish that was not coming directly had been given feed, because the seed goldfish pets require adapting to the new media. This adaptation is required for 7 days, the feed given after the fish look healthy and aggressive. Feeding is done twice per day, at 08.00 and 15.00 hours. Every day after feeding, supporting measurement parameters such as temperature, salinity, $\mathrm{pH}$ and dissolved oxygen to maintain the environmental conditions remain normal for goldfish.

\subsection{Isolation of Crude Protein from Halimeda sp}

Isolation protein was referred to Laemmli (1970) [9]. Halimeda sp. 50 gr laid in mortar and crushed with a speed for 1 hour, then add liquid nitrogen and crushed again for 1 hour. Adding resuspension buffer glycine $+\mathrm{KCL}$ as much as 8 $\mathrm{ml} .2 \mathrm{~g}$ sample is weighed and put in a ependof , then centrifuged in cold at $4^{\circ} \mathrm{C}, 17000 \mathrm{rpm}$ for 60 minutes. Supernatant was taken and placed in a sterile ependorf. Supernatant was added with a solution of solid ammonium sulfate (SAS) 30\% of the supernatant. Sentrifuge at $15000 \mathrm{rpm} ; 4^{\circ} \mathrm{C}$; $30 \mathrm{~min}$. Supernatant removed and transferred to a sterile eppendof and measurement of quantitative of crude protein Halimeda sp using spectrofotometry with specific wave long of protein $280 \mathrm{~nm}$.

\subsection{Induction of crude protein from Halimeda in Cyprinus carpio}

Before treatment, fish (15 cm in length) was acclimated in the batch (aquarium) for 7 days with controlled environment parameter. Tests were conducted by oral (sonde method) using a hose feeding tube four times. Sonde process was carried out on the first day, $5^{\text {th }}, 9^{\text {th }}, 13^{\text {th }}, 23^{\text {th }}, 27^{\text {th }}$, days with dose of $307 \mu \mathrm{L}, 321 \mu \mathrm{L}, 331 \mu \mathrm{L}, 336$ $\mu \mathrm{L}, 346 \mu \mathrm{L}$, and $376 \mu \mathrm{L}$, respectively with protein concentration stock that results from spectrofotometry was $33 \mathrm{mg} / \mathrm{l}$. After treatment, and then the fish was dissected to collect eye and brain organ respectively.

\subsection{Induction of Koi Herpes Virus into Cyprinus carpio}

An induction method performed orally. The fish feed was inserted into positive carp meat infected with KHV. Dose forage for a meal as much as $3-5 \%$ of the weight of the fish. Feeding the infected fish uses a crude protein after $9^{\text {th }}$ day at the afternoon. Further feeding was done regularly for 2 times a day at the evening time only. Treatment was carried out until day 23 of treatment. Observe any change in fish behavior every hour until visible symptoms of whirling (swirling movement without direction). All fish treatment is maintained and observed from day 1 to day 27 then be harvested.

\subsection{Haemaglutination test}

Haemagglutination test was conducted based on Hanne and Finkelstein (1982) [10]. Fish blood isolated from the normal fish using a syringe $1 \mathrm{ml}$ $26 \mathrm{GX}^{1} \frac{1}{2}$ " (Therumo) previously moistened with a solution of $10 \%$ EDTA. Fresh blood is subsequently washed twice using PBS, homogenized and then centrifuged at 3500 RPM for 10 minutes. Erythrocyte further diluted using PBS $(1: 200)$ for use in a HA test.

\subsection{Dot blot methods}

Dot blot methods were conducted using Biorad's semi dry blotter. The electric current of $300 \mathrm{~mA}$ was applied for $30 \mathrm{~min}$, followed by dyeing $2 \%$ poncho containing $3 \%$ trichloro acetic 
acid. After that, the blot was transferred to the nitrocellulose paper and rinsed using $\mathrm{dH}_{2} \mathrm{O}$ to eliminate the poncho dye and then the paper was blocked using TBE at $\mathrm{pH} 7.4$ with the supplement of $3 \%$.

\subsection{Data analysis}

Data was analyzed using descriptive analysis. The quantification of the dot blot result was conducted using the software of ImageJ version 1.48 .

\section{RESULT AND DISCUSSION}

Previous research conducted Rodriguez et al (2017) revealed that they have evaluated the effect of algal proteins to increase the immune response of red drum, Sciaenops ocellatus. [ 11 ]. Proteins can serve as a surface antigen that could stimulate an immune response specific and non specific in vertebrate organisms. This is what can be used as the basis of biological material that is crude protein from marine macroalgae Halimeda soup to stimulate the fish's immune system against infectious viral diseases.

Protein band profiles of SDS-PAGE analysis results can be seen in Figure 1.
The expression of MHC related to the mechanism of antigen presenting cells (APC) $\mathrm{APC}$ is a cell that displays MHC - antigen complexes on all its surfaces. APC cells with MHC molecules that have been activated by antigens play an important role in initiating CD8 $\mathrm{T}$ cell responses against intracellular microbial antigens. In this study, the expression of MHC class I on the organ Cyprinus carpio was triggered by the presence of antigen in the form of crude protein from Halimeda and KHV.

The result of Haemagglutination Test (HA) showed a positive reaction to the eye organ started dilution $1 / 2,1 / 4,1 / 8,1 / 16,1 / 32$, and $1 / 64$ to dilution. A positive reaction is shown by the absence of the erythrocyte sedimentation on the basis of well microplate, was shown in Table 1 .

Observations on the exposed fish virus $\mathrm{KHV}$, both on the eyes and brain organ obtained the highest titers up to $1 / 64$, which means positive reactions occur until the HA test at 64 times dilution. A positive reaction is shown by the absence of a dot at the bottom of a well. So the magnitude of the value of adhesion molecules reaches $2^{6}$.

The induction of crude protein in the organs

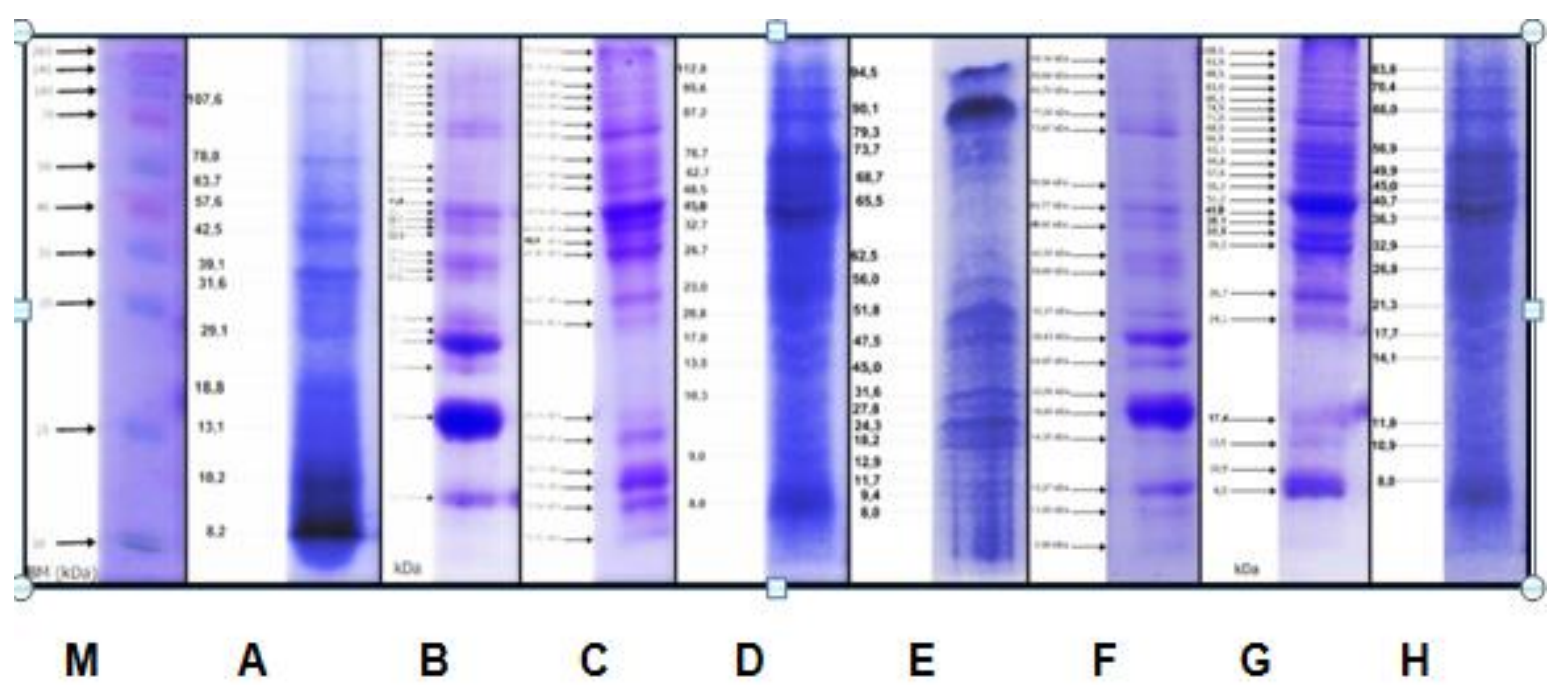

Figure 1. Protein Profile of Multiple Organ Goldfish Treatment Using SDS - PAGE M = Marker, A = Fisheye Control, B = Fisheye + Crude Protein, $\mathrm{C}=$ Fisheye + Crude $+\mathrm{KHV}, \mathrm{D}=$ Fisheye + $\mathrm{KHV}, \mathrm{E}=$ Brain Control Fish, Fish $+\mathrm{F}=$ Brain Crude, $\mathrm{G}=$ Brain + fish + Crude KHV, $\mathrm{H}=$ Brain KHV + fish

Based on the observation of the expression of MHC I molecules on the image above shown the molecule is expressed in the target organ is the eye and brain in all treatments except the control fish, with a molecular weight of $45 \mathrm{kDa}$. MHC class I is a heterodimer that is expressed on the surface of mast cells that have a nucleus, consisting of an alpha chain (molecular weight 45 $\mathrm{kDa})$ [8].
Halimeda sp both eyes and brain test showed a positive reaction to the dilution $1 / 32$. HA concentrations up to a dilution of $1 / 32$ showed that the reaction between the crude protein agglutination with erythrocytes goldfish has a titer value adhesion reached 25 . The elevated specific antibody titers will increase the protection function in the fish. Antibody titer of $1 / 16-1 / 80$ able to neutralizing effect of Viral Septicemia Hemorrhagic Virus in the fish [12]. 
Conditions of fish in a healthy state due to the induction of PCP Halimeda sp capable of triggering the production of adhesion molecules and cytokines by immune cells. Namely MHC I molecules that have a role in the antiviral effect of carp. The result of MHC I expression was shown in Table 2.

The highest color quantification of the dot was obtained in the brain organ of fish induced by Halimeda sp and KHV with value 153.22. The highest color quantification means the highest titer antibodies produced so MHC I expression was stronger. can be used as tools to detect and diagnose diseases.

\section{Conclusion}

Crude protein of Halimeda in this research is to modulate the immune resistance of carp (Cyprinus carpio). To determine the success of antiviral potency of these results can be known by the expression of MHC class I as a result of the grant of crude protein Halimeda sp. So that the molecule is capable of functioning as an inhibitor of proliferation of Koi Herpes Virus (KHV). The results of this study provide an

Table 1.

Haemaglutination Test of Coat Protein KHV

\begin{tabular}{|c|c|c|c|c|c|c|c|}
\hline \multirow[t]{2}{*}{ Sample } & \multicolumn{6}{|c|}{ Dilution } & \multirow[t]{2}{*}{ Control } \\
\hline & $1 / 2$ & $1 / 4$ & $1 / 8$ & $1 / 16$ & $1 / 32$ & $1 / 64$ & \\
\hline Eye Control & - & - & - & - & - & - & - \\
\hline Eye+Halimeda & + & + & + & + & + & - & - \\
\hline Eye+Ha limeda+KHV & + & + & + & + & + & + & - \\
\hline Eye+KHN & + & + & + & + & + & + & - \\
\hline Brain Control & - & - & - & - & - & - & - \\
\hline Brain+Halimeda & + & + & + & + & + & - & - \\
\hline Brain+Halimeda+KHV & + & + & + & + & + & + & - \\
\hline Brain+KHV & + & + & + & + & - & - & - \\
\hline
\end{tabular}

Table 2.

Analysis of dot blot reaction of crude protein with anti-MHC I

\begin{tabular}{|l|l|l|l|l|c|c|c|c|}
\hline Organ & $\begin{array}{l}\text { Control } \\
\text { Eye }\end{array}$ & $\begin{array}{l}\text { Eye }+ \\
\text { hali-meda }\end{array}$ & $\begin{array}{c}\text { Eye + hali- } \\
\text { meda + KHV }\end{array}$ & $\begin{array}{c}\text { Eye }+ \\
\text { KHV }\end{array}$ & $\begin{array}{c}\text { Control } \\
\text { brain }\end{array}$ & $\begin{array}{c}\text { Brain + } \\
\text { Halimeda }\end{array}$ & $\begin{array}{c}\text { Brain + Hali- } \\
\text { meda + KHV }\end{array}$ & $\begin{array}{c}\text { Brain }+ \\
\text { KHV }\end{array}$ \\
\hline $\begin{array}{l}\text { Dot } \\
\text { blot }\end{array}$ & $*$ & - & - & $\mathbf{6}$ & $*$ & $\mathbf{6}$ & $\mathbf{6}$ & \\
\hline $\begin{array}{l}\text { Quanti- } \\
\text { fication* }\end{array}$ & 40.96 & 88.38 & 145.12 & 79.63 & 20.58 & 77.23 & 153.22 & 75.66 \\
\hline
\end{tabular}

*color indication: 1 for full white, 255 for full black

Lowest quantification results are shown in the control fish organs with a value of 20.58 and 40.96, this is because in normal fish MHC class I is not expressed strongly because there is no activity of inducers of crude protein and KHV.

When animals are exposed to antigens, they generate an immune response and produce antibodies (proteins) that recognize and bind tightly to the specific antigens. Each antibody recognizes only a single antigen. Scientists have learned to use the immune response of animals to make antibodies that explanation that the crude protein of Halimeda sp. potential as antiviral biological material as a viral disease control efforts in fisheries resources.

It concludes that molecules MHC I are expressed in brain and eye due to the influence of treatment of crude protein macroalgae Halimeda sp. Crude protein of Halimeda sp can be used as material for antiviral KHV in Cyprinus carpio.

\section{ACKNOWLEDGEMENT}

Thanks to the State Ministry of Research, Technology and Higher Education Republic of Indonesia for research grant 2017. 


\section{REFERENCES}

[1] Madigan, M.T., J.M. Martinko, dan J. Parker. 2003. Brock Biology of Microorganisms, Tenth edition. Prentice Hall, Pearson education, Inc., New Jersey. 1019p.

[2] Janeway Jr., C.A., P. travers, M. Walport, M.J. Shlomchik. 2001. Immunobiology : the immune sytem in health and disease 5th ed. Garland Publishing, New York.

[3] Dixon, B., K. E. Magor, B. P. Shum, and P. Parham. 1996. Major (Oncorynchus mykiss). Departement of Structural Biology Fairchild Center, Stanford University School of Medicine, California

[4] Hansen, T. H. and Bouvier, M. 2009. MHC class I antigen presentation: learning from viral evasion strategies. Nat. Rev. Immunol. 9 (7), pp. 503-13

[5] Costes, B., Raj, V. S., Michel, B., Fournier, G., M. Thirion, L. Gillet, J. Mast, F. Lieffrig, M. Bremont, and A. Vanderplasschen. 2009. The Major Portal of Entry of Koi Herpesvirus in Cyprinus carpio Is the Skin, $J$. Virol. 83 (7), pp. 2819-2830.

[6] Gomez, D. K., Joh,S. J., Jan, H., Shin, S. P., Choresca, C. H., Han, J. E., Kim, J. H., Jun, J. W., and Park, S. C. 2011. Detection of koi herpesvirus (KHV) from koi (Cyprinus carpio koi) broodstock in South Korea. Aquaculture 311 (1-4): pp. 42-47.

[7] Ahmad, A., H. Usman., H. Natsir., A. Karim. 2014. Isolation and characterization of bioactive protein from green algae Halimeda macrobola acting as antioxidant and anticancer agent. American Journal of Biomedical and Life Sciences. 2014; 2(5): 134-140

[8] Pandey, J.P. 2007. Major Histocompatibility Complex In Virella, G (Ed). Medical Immunology sixth edition. Informa Healthcare, New York. p: 23-34[6]

[9] Laemmli, U. K. 1970. Cleavage of structural proteins during the assembly of the head of bacteriophage T4. Nature 227(5259): 680685

[10] Hanne, L. F. and R. A. Finkelstein. 1982. Characterization and distribution of the hemagglutinins produced by Vibrio cholerae. Infect. Immun. 36:209-214

[11] Rodriguez, M.G.., Pohlenz, C., Gatlin, D.M., 2017. Supplementation of organic acids and algae extracts in the diet of red drum Sciaenops ocellatus : immunological impacts. Aquac. Res. 48, 1778-1786.

[12] Wilson, A., Goldberg, T., Marcquenski, S., Olson, W., Goetz, F., 2014. Development and Evaluation of a Blocking EnzymeLinked Immunosorbent Assay and Virus Neutralization Assay To Detect Antibodies to Viral Septicemia Hemorrhagic Virus. Clin. Vaccine Immunol 21, 435-442. 